\title{
Frequency of Incidental Cancer in Transurethral Prostate Resection Materials and Our Clinical Approach to These Patients; a Retrospective File Scan
}

\author{
Transüretral Prostat Rezeksiyonu Materyallerindeki Insidental Kanser Sıklığı ve Bu \\ Hastalardaki Klinik Yaklașımımız; Geriye Dönük Dosya Taraması
}

\author{
Caner Özbey ${ }^{1}$, Kenan Öztorun ${ }^{2}$ \\ ${ }^{I}$ Niğde Ömer Halisdemir University, Faculty of Medicine, Department of Pathology; ${ }^{2}$ Department of Urology, Niğde, Turkey
}

\begin{abstract}
Aim: This study aims to determine the incidence of cancer in patients who underwent transurethral resection of the prostate (TUR-P) due to bladder outlet obstruction and to share our clinical approach to these patients at Niğde Ömer Halisdemir University Training and Research Hospital.

Material and Method: The pathology reports of 650 TUR-P specimens from January 1, 2012, to December 31, 2017, were retrospectively screened. In the pathology results of the prostatic adenocarcinoma patients, the age, tumor stage and Gleason score (GS) were evaluated. Physical examination data and the serum total Prostate Specific Antigen (PSA) levels, as well as the radiological findings, were analyzed according to the hospital records.

Results: After excluding nine patients with known prostate carcinoma there were 15 adenocarcinomas out of 641 patients (2.34\%). The mean age was 72 . Eleven patients were diagnosed as GS 6, and four patients were diagnosed with GS 7 prostate adenocarcinoma. Serum total PSA levels ranged from 1.56 to $9.22 \mathrm{ng} / \mathrm{mL}$. T1a tumor was detected in 11 patients and T1b tumor in 4 patients.
\end{abstract}

Conclusion: Considering the studies that reported incidental prostate cancer (IPC) rates in the PSA era, our rate is close to the lower limit. The application of primary therapies should not be avoided in patients with IPC after TUR-P.

Key words: incidental prostate cancer; transurethral resection; PSA

\section{ÖZET}

Amaç: Çalıșma, Niğde Ömer Halisdemir Üniversitesi Eğitim ve Araștırma Hastanesi (EAH)'nde mesane çıkıș obstrüksiyonu nedeniyle transüretral prostat rezeksiyonu (TUR-P) uygulanan hastalardaki kanser sıkı̆̆ını belirlemek ve bu hastalardaki klinik yaklașımımızı paylașmayı amaçlamaktadır.

Caner Özbey, Niğde Ömer Halisdemir University, Faculty of Medicine, Department of Pathology, Niggde, Turkey,Fax.03882252582Email.canerozbey@obu.edu.tr Geliş Tarihi: 03.01.2019 • Kabul Tarihi: 11.03.2019
Materyal ve Metot: 1 Ocak 2012-31 Aralık 2017 tarihleri arasındaki 650 TUR-P materyaline ait patoloji sonuç raporu geriye dönük olarak tarandı. Patoloji sonuç raporlarında prostatik adenokarsinom tanılı hastaların yașı, tümörün evresi ve Gleason skoru (GS), hastanemizin bilgi yönetim sisteminde serum total PSA düzeyleri, fizik muayene ve görüntüleme bulguları tarandı.

Bulgular: Bilinen prostat kanseri tanısı olan 9 hasta çıkarıldığında 641 hastadan 15 'inde $(\% 2,34)$ adenokarsinom saptandı. Ortalama yaș 72 olup 11 hasta GS 6, 4 hastada GS 7 prostat adenokarsinomu tanısı almıștı. Serum total PSA düzeyleri 1,56 ile 9,22 ng/ $m L$ arasında değișmekteydi. 11 hastada T1a, 4 hastada T1b tümör saptandı.

Sonuç: Serum PSA düzeyleri ölçümlerinin yaygın olarak kullanılmaya bașlamasından sonra yapılan insidental prostat kanseri (IPK) oranlarını bildiren çalıșmalar değerlendirildiğinde bizim oranımız alt sınıra yakındır. TUR-P sonrası IPK saptanan hastalarda birincil tedavilerin uygulanmasından kaçınılmamalıdır.

Anahtar kelimeler: insidental prostat kanseri; transüretral rezeksiyon; PSA

\section{Introduction}

Prostate cancer is the second most common type of cancer in men. Autopsy series showed up to $80 \%$ latent prostate cancer over 80 years old ${ }^{1}$. Transurethral resection of prostate (TUR-P) is considered as standard surgical treatment modality for treating benign prostatic hyperplasia $(\mathrm{BPH})$. Incidental prostate cancer (IPC) is defined as the prostate cancer, which is not evident clinically by digital rectal examination (DRE) or imaging methods. Today, with prostate-specific antigen (PSA) screening in serum, the incidence IPC in TUR-P specimens is low. In the pre-PSA era the rate of IPC was high up to $27 \%$. Today the prevalence of IPC is reported to vary between $1.4-16.7 \%$ in different studies ${ }^{2,3}$. 
It has been reported that radical prostatectomy is associated with low mortality compared to watchful waiting in early prostate cancer treatment and the benefit rate from oncologic surgical treatment was found to be higher in patients 65 years and younger ${ }^{4}$.

Prostate carcinoma often arises from peripheral zone (PZ) while TUR-P targets the transitional zone (TZ) of the prostate. Studies emphasize that TZ originated prostate cancer has a better prognosis than prostate cancer located in the $\mathrm{PZ}$.

Prostate adenocarcinoma is an important cause of morbidity and mortality. Incidental adenocarcinoma cases should be treated with appropriate methods after clinical staging. In some IPC cases clinical course can become unfavorable and further treatments can be costly. In the literature, the prevalence of IPC is reported at different rates in studies from different centers. This is often due to sampling differences by pathologists or due to differences in laboratory and radiological screening protocols for predicting carcinoma prior to TUR-P. In this study, we aimed to determine the incidence of cancer in patients who underwent TUR-P for $\mathrm{BPH}$ treatment, compare our rate with the literature and to share our clinical approach to these patients in our center.

\section{Material and Method}

Our study is planned as a descriptive retrospective research. The pathology result reports of 650 TUR-P specimens from January 1, 2012 to December 31, 2017 were retrospectively screened at Niğde Ömer Halisdemir University School of Medicine, Training and Research Hospital. In the pathology result reports with prostatic adenocarcinoma age, tumor stage and Gleason score (GS) were evaluated. Patients with known prostate cancer who underwent TUR-P for palliative purposes were excluded from the study.

The sample size calculation was not included due to the design of our study. The number of cases examined in our study was considered as tumor positive patients who were admitted to the urology clinic in our center for TUR-P and they were the whole population for incidental prostate carcinoma.

Regarding processing of TUR-P chips, guidelines of College of American Pathologists (CAP) were followed. All the specimens were weighed, then the specimens that weigh $12 \mathrm{~g}$ or less submitted in their entirety. For specimens that weigh more than $12 \mathrm{~g}$, the initial 12 g were submitted and 1 cassette for every additional $5 \mathrm{~g}$ was submitted. In case of high grade prostatic intraepithelial neoplasia (H-PIN) or IPC, all remaining TUR material were submitted for histopathologic evaluation. Sections at a thickness of $4 \mu \mathrm{m}$ were cut from formalin fixed paraffin embedded tissues and stained with hematoxylin-eosin.

For evaluating the GS, the primary and the secondary histologic patterns of tumor were scored ranging 1 to 5. Combined GS was determined by addition of scores of these two most common morphological patterns. If a tumor had only one histologic pattern, then score of that pattern was doubled to find the combined GS.

For determining the clinical stage of the tumor, the percentage of tissue involved by carcinoma was reported, with $5 \%$ the cutoff between $\mathrm{T} 1 \mathrm{a}$ and $\mathrm{T} 1 \mathrm{~b}$ disease

In our hospital's information management system serum total PSA levels, physical examination and imaging findings were also screened for patients with adenocarcinoma.

Our study was conducted in accordance with the Guidelines for Good Clinical Practice and the Declaration of Helsinki. Niğde Ömer Halisdemir University Ethics Committee has approved our study by the 2018/10-04 decision.

\section{Results}

After excluding 9 patients with known prostate carcinoma, who underwent palliative TUR-P for bladder outlet obstruction, there were 15 adenocarcinomas out of 641 patients $(2.34 \%)$. The mean age was 72 (ranging from 59 to 81 ). 11 patients had GS $3+3=6$, 3 patients had $3+4=7$ and 1 patient had $4+3=7$ prostatic adenocarcinoma (Figure 1,2). T1a tumor was detected in 11 patients and $\mathrm{T} 1 \mathrm{~b}$ tumor in 4 patients. $3(20 \%)$ of the patients with cancer were 65 years of age and younger while 12 patients (80\%) were over 65 years of age. All patients under 65 years of age had T1a and combined GS 6 tumors. Serum total PSA levels ranged from 1.56 to $9.22 \mathrm{ng} / \mathrm{mL}$ among all 15 patients with carcinoma.

There are different approaches to the prostate needle biopsy decision in patients with no abnormal findings in DRE, with $2.5 \mathrm{ng} / \mathrm{mL}$ and $4 \mathrm{ng} / \mathrm{mL}$ as the upper limit of PSA. In our practice we use PSA threshold of $4.0 \mathrm{ng} / \mathrm{mL}$ for men over 60 years of age and $2.5 \mathrm{ng} / \mathrm{mL}$ for men between 50-60 years of age. If there is no abnormality in DRE in patients with a PSA value below 


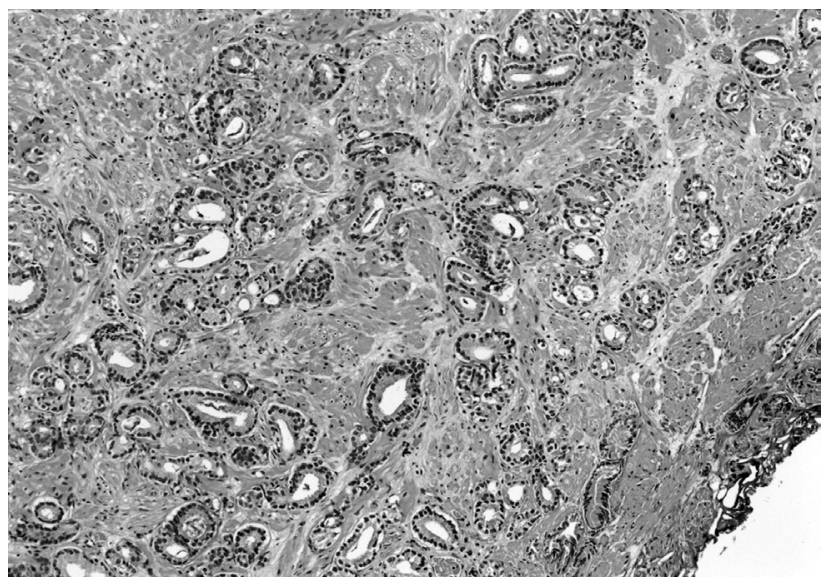

Figure 1. Well-formed, individual glands of various sizes including branching glands with intervening stroma. Focus of Gleason pattern 3 prostatic adenocarcinoma. (HEx100)

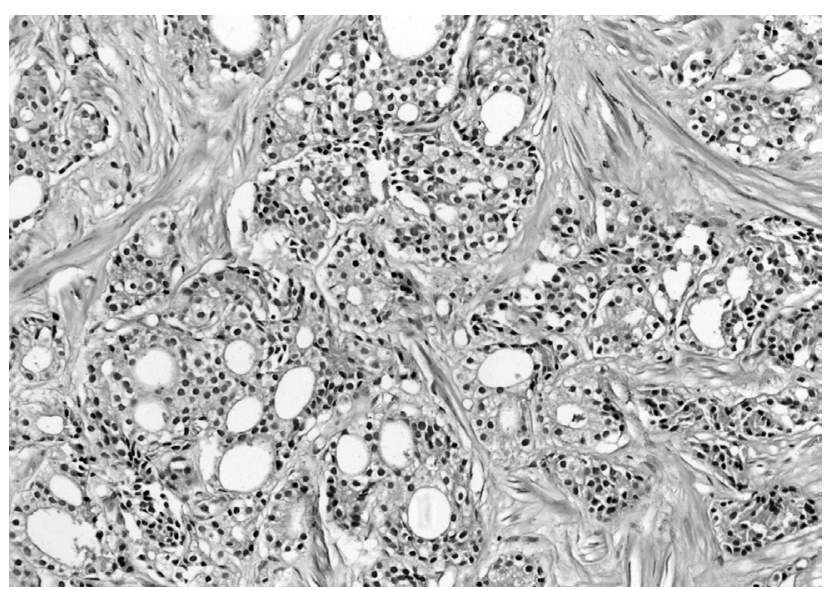

Figure 2. Poorly-formed, fused, and cribriform glands. Focus of Gleason pattern 4 prostatic adenocarcinoma. (HEx200)
$2.5 \mathrm{ng} / \mathrm{mL}$, no additional examination is performed. 5 patients with IPC had PSA values below $2.5 \mathrm{ng} / \mathrm{mL}$ (ranging from 1.56 to 2.2, mean 1.87) and no additional examination was performed prior to the operation due to the absence of abnormal findings in DRE. The mean age of these 5 patients was 69.2 (ranging from 59 to 79) and GS 6 prostatic adenocarcinoma was detected in all. The clinical stage of 4 patients was reported as T1a and the clinical stage of 1 patient was T1b (PSA $2.05 \mathrm{ng} / \mathrm{mL}$, age 68). The biopsy results of these $5 \mathrm{pa}-$ tients were confirmed as GS 6 in the postoperative period. 4 patients with T1a is in active surveillance. 1 patient with $\mathrm{T} 1 \mathrm{~b}$ was informed about active surveillance, radical prostatectomy, radiotherapy and brachytherapy options. The patient chose the intensity modulated radiotherapy (IMRT). There is no biochemical recurrence in 3 years follow-up.

Screening for prostate carcinoma is recommended for patients who have a life expectancy of at least 10 years. Therefore, in patients over 80 years of age, there are approaches to avoid PSA screening if they are not symptomatic in terms of metastases that may be related to prostate carcinoma. In our study, two patients with IPC were above 80 years of age and PSA examination was performed due to surgical treatment planning $(81$ y, PSA $9.13 \mathrm{ng} / \mathrm{mL}$, GS 3+3=6, T1a-80 y, PSA 7.09 $\mathrm{ng} / \mathrm{mL}, \mathrm{GS} 3+4=7, \mathrm{Tla})$. The patients were informed about the risk of prostate cancer due to elevated PSA levels but they did not want to perform the recommended prostate needle biopsy under guidance of transrectal ultrasonography. No metastases were detected in postoperative evaluation. One of the patients died at the 6th postoperative month due to chronic obstructive pulmonary disease. No additional treatment was given to the other patient due to the lack of PSA elevation.

The mean age of the other 8 patients was 71.6 (ranging from 59 to 76), and the mean PSA was $6.11 \mathrm{ng} /$ $\mathrm{mL}$ (ranging from 4.41 to 9.22). 5 patients had T1a tumors with GS of $3+3=6$ while 2 patients had $\mathrm{T} 1 \mathrm{~b}$ tumor with GS $3+4=7$ and 1 patient had T1b tumor with GS $4+3=7.6$ patients underwent TUR-P operation after benign preoperative TRUSG + prostate needle biopsy results. The mpMRI results of 2 patients were evaluated as PI-RADS 3 (intermediate risk, clinically significant cancer is equivocal). These patients showed symptoms of severe bladder outlet obstruction and they did not want to undergo additional examination but they requested surgical treatment (Table 1,2).

\section{Discussion}

PSA is a serine protease secreted from prostate epithelial cells and serum PSA levels may also increase in benign pathologies such as BPH and prostatitis ${ }^{6-8}$. In T1 a tumors and tumors with low GS it may not elevate enough to suggest cancer. In patients with serum total PSA levels above $4 \mathrm{ng} / \mathrm{mL}$, it is recommended to exclude prostate cancer before TUR-P with prostate 
Table 1. Clinical and pathological data of $P S A<4$ patients

\begin{tabular}{|c|c|c|c|c|c|}
\hline Age & $\begin{array}{l}\text { PSA } \\
(\mathrm{ng} / \mathrm{mL})\end{array}$ & DRE & Prostate volume & GS & Stage \\
\hline 79 & 1.56 & $\begin{array}{l}\text { Grade 1, Benign } \\
\text { Consistency }\end{array}$ & $46 \mathrm{cc}$ & $3+3=6$ & T1a \\
\hline 59 & 1.85 & $\begin{array}{l}\text { Grade 1, Benign } \\
\text { Consistency }\end{array}$ & $52 \mathrm{cc}$ & $3+3=6$ & T1a \\
\hline 68 & 2.05 & $\begin{array}{l}\text { Grade } 1.5, \text { Benign } \\
\text { Consistency }\end{array}$ & $68 \mathrm{cc}$ & $3+3=6$ & T1b \\
\hline 65 & 1.72 & $\begin{array}{l}\text { Grade 1, Benign } \\
\text { Consistency }\end{array}$ & $48 \mathrm{cc}$ & $3+3=6$ & T1a \\
\hline 75 & 2.2 & $\begin{array}{l}\text { Grade } 1.5, \text { Benign } \\
\text { Consistency }\end{array}$ & $73 \mathrm{cc}$ & $3+3=6$ & T1a \\
\hline
\end{tabular}

PSA, prostate specific antigen; DRE, digital rectal examination; GS, Gleason score.

Table 2. Clinical and pathological data of $P S A>4$ patients

\begin{tabular}{|c|c|c|c|c|c|c|}
\hline Age & PSA (ng/mL) & DRE & Prostate volume & MpMRI & GS & Stage \\
\hline 76 & 6.3 & Grade 1, Asymmetric Right Lobe & $55 \mathrm{cc}$ & - & $4+3=7$ & T1a \\
\hline 59 & 5.04 & Grade 1, Benign Consistency & $41 \mathrm{cc}$ & - & $3+3=6$ & T1a \\
\hline 75 & 5.06 & Grade 1.5, Benign Consistency & $63 \mathrm{cc}$ & PIRADS 3 & $3+3=6$ & T1a \\
\hline 76 & 8.86 & Grade 1.5, Fibrotic Consistency & $72 \mathrm{cc}$ & - & $3+3=6$ & T1a \\
\hline 70 & 4.41 & Grade 1, Benign Consistency & $45 \mathrm{cc}$ & PIRADS 3 & $3+3=6$ & $\mathrm{~T} 1 \mathrm{~b}$ \\
\hline 71 & 5.6 & $\begin{array}{l}\text { Grade 1, } \\
\text { Asymmetric Left Lobe }\end{array}$ & $58 \mathrm{cc}$ & - & $3+4=7$ & T1b \\
\hline 72 & 9.22 & Grade 2, Benign Consistency & $85 \mathrm{cc}$ & - & $3+3=6$ & T1a \\
\hline 74 & 4.44 & Grade 1, Benign Consistency & $57 \mathrm{cc}$ & - & $3+4=7$ & T1b \\
\hline 81 & 9.13 & Grade 1.5, Fibrotic Consistency & $69 \mathrm{cc}$ & - & $3+3=6$ & T1a \\
\hline 80 & 7.09 & Grade 1, Benign Consistency & $56 \mathrm{cc}$ & - & $3+3=6$ & T1a \\
\hline
\end{tabular}

needle biopsy. In recent years, this rate is recommended to withdraw to $2.5 \mathrm{ng} / \mathrm{mL}^{9}$.

Many studies have compared IPC rates between the pre-PSA and the PSA era. Tombal et al. reported that the rate of IPC decreased from $27 \%$ to $9 \%$ comparing their pre-PSA era to PSA era IPC detection rates and the frequency of $\mathrm{T} 1 \mathrm{~b}$ tumors decreased from $15 \%$ to $2 \%$ in 1648 patients. In a similar study with 982 patients, Mai et al. reported that the rate of IPC decreased from $12.9 \%$ to $8 \%$ and the rate of $\mathrm{T} 1 \mathrm{~b}$ tumor from $10 \%$ to $5 \%$. There were no significant changes in T1a tumor rates in both studies ${ }^{10,11}$.

In a study with 120 TUR-P materials by Güvendi et al., the IPC rate was found to be $2.5 \%$. The authors emphasize that the number of IPCs has decreased in recent years with the increase in clinical experience and the malignancy has begun to be diagnosed prior to TUR-P ${ }^{12}$. In a multicenter study by Yoo et al., the IPC rate was found to be $4.8 \%$. The authors emphasize that, in addition to DRE findings, the PSA level and the evaluation of $\mathrm{TZ}$ volume together will provide more reliable information for IPC ${ }^{13}$.

In five year period, Otto et al. and Khan et al., in two separate studies, reported the rate of IPC in TUR-P specimens $1.4 \%$ and $1.8 \%$, respectively. For these low rates, researchers suggest that their pre-TUR needle biopsy rates might be higher than other centers' rates $^{2,14}$. In the PSA era, Trpkov et al. reported a high IPC rate 


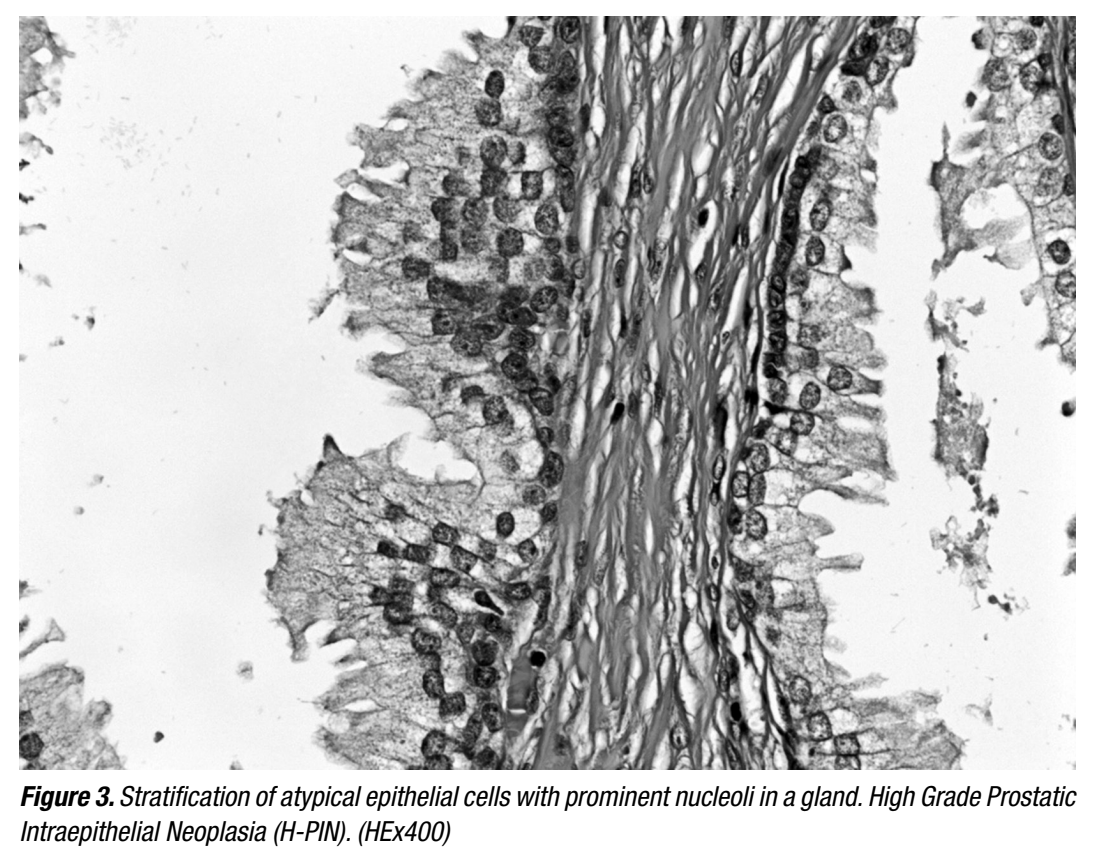

of $16.7 \%$. However, the fact that patients with known prostate carcinoma are included in the study explains this high rate ${ }^{15}$.

In our study, when known prostate carcinoma patients are excluded, the rate of IPC is $2.34 \%$. Considering the studies reporting IPC rates in the PSA era, our rate is close to the lower limit (\% 1.4-16.7 $)^{2,13-17}$. One of the reasons for this may be that prostate needle biopsy prior to TUR-P due to PSA elevation has become more widespread in recent years. In addition, as a limitation of our study, not all TUR-P specimens were sampled for microscopic examination. As in some T1a tumors, cancerous tissue is detected in a single block, we might have underdiagnosed malignancy cases due to not sampling all chips, which may be a cause of our low cancer rate.

This study has other limitations too. Retrospective study design, lack of sample size calculation, only one central's results are mainly limited the power of this study and the results are not generalizable to community settings.

The use of mpMRI in our clinic in some of the period covered by our study provides advantages over previous publications. We suggest that increased use of MR fusion prostate biopsy will lead to increase in detection of cancer in biopsies and therefore decrease in IPC, especially in clinically significant prostate cancer rates.

$\mathrm{H}-\mathrm{PIN}$ is considered as a precursor lesion of prostate cancer and has similar genetic and molecular alterations as carcinoma. The presence of H-PIN in TUR-P material should alert the pathologist to process all TUR-P specimen for microscopic examination ${ }^{18-19}$ (Figure 3).

For localized prostate cancer cases, in the low-risk group (T1 c-T2a, GS $\leq 6$, PSA $\leq 10 \mathrm{ng} / \mathrm{mL}$ ) active surveillance may be an option. Besides, curative treatment options such as radical prostatectomy, radiotherapy, brachytherapy, high intensity focused ultrasound can be offered ${ }^{20}$.

In the cases with IPC, the understanding that radical prostatectomy cannot be performed due to the wound healing fibrosis in the postoperative period and complications such as incontinence or erectile dysfunction will be seen more frequently is being abandoned in recent years. Radical prostatectomy or localized treatment options can be performed following TUR-P ${ }^{19-21}$.

We increased the number of cases by performing the archive scanning interval in the widest time interval allowed by the system thus, we aimed to reduce the potential confounding effects by increasing the total number of patients. 
As a result, we demonstrated an IPC rate of $2.34 \%$. Considering the studies that reported IPC rates in the PSA era, our rate is close to the lower limit. Despite the widespread use of biochemical markers and imaging modalities, IPC is detected in TUR-P materials even in a low rate. The application of primary therapies should not be avoided in patients with IPC after TUR-P.

Since the presence of cancer in prostate cannot be precisely excluded before the operation, we recommend sampling TUR-P specimens for their entirety for microscopy. Considering the patients who will lose their chances of treatment due to lack of sampling, we think such practice will be beneficial considering the cost implications.

\section{References}

1. Bostwick D, Cheng L. Chapter 9: Neoplasms of the prostate. In: Bostwick D, ed. Urologic surgical pathology 2nd ed. Portland: Mosby Elsevier; 2008:410-3.

2. Otto B, Barbieri C, Lee R, Te AE, Kaplan SA, Robinson B, et al. Incidental prostate cancer in transurethral resection of the prostate specimens in the modern era. Adv Urol 2014;6272-90.

3. Adolfsson J. The management of category T1a-T1b (incidental) prostate cancer: can we predict who needs treatment? Eur Urol 2008;54(1):16-8.

4. Bill-Axelson A, Holmberg L, Garmo H, Rider JR, Taari K, Busch C, et al. Radical prostatectomy or watchful waiting in early prostate cancer. N Engl J Med 2014;370:932-42.

5. Augustin H, Erbersdobler A, Graefen M, Fernandez S, Palisaar $\mathrm{J}$, Huland $\mathrm{H}$, et al. Biochemical recurrence following radical prostatectomy: a comparison between prostate cancers located in different anatomical zones. Prostate 2003;55:48-54.

6. Lilja H. A kallikrein like serum protease in prostatic fluid cleaves the predominant seminal vesicle protein. J Clin Invest 1985;76:1899-903.

7. Morote J, Lopez M, Encabo G, de Torres IM. Effect of inflammation and benign prostatic enlargement on total and free serum prostate specific antigen. Eur Urol 2000;37:537-40.

8. Malkoç E, Ateş F, Uğuz S, Dursun F, Karademir AK, Adayener C, et al. Histolojik olarak kanıtlanmış kronik prostatit ile PSA dansitesi arasındaki ilişki. Gülhane Tıp Derg 2013;55:18-21.

9. Catalona WJ, Ramos CG, Carvalhal GF, Yan Y. Lowering PSA cutoffs to enhance detection of curable prostate cancer. Urology 2000;55:791-5.
10. Tombal B, De Visccher L, Cosyns JP, Lorge F, Opsomer R, Wese FX, et al. Assessing the risk of unsuspected prostate cancer in patients with benign prostatic hypertrophy: a 13-year retrospective study of the incidence and natural history of T1aT1b prostate cancers, BJU Int 1999;84(9):1015-20.

11. Mai KT, Isotalo PA, Green J, Perkins DG, Morash C, Collins JP. Incidental prostatic adenocarcinomas and putative premalignant lesions in TURP specimens collected before and after the introduction of prostrate-specific antigen screening, Arch Pathol Lab Med 2000;124(10):1454-6.

12. Güvendi FG, Toyran T, Bağcıŏlu M, Kılıç Ö, Adalı Y. The incidence and significance of incidental prostate carcinoma in transurethral resection (TUR-P) materials between 2014 and 2016 at Our Center, Medical Sciences (NWSAMS) 2018;13(2):19-22.

13. Yoo C, Oh CY, Kim SJ, Kim SI, Kim YS, Park JY, et al. Preoperative clinical factors for diagnosis of incidental prostate cancer in the era of tissue ablative surgery for benign prostatic hyperplasia: A Korean multi-center review. Korean J Urol 2012;53(6):391-5.

14. Khan MA,Shah HU, Gul M, Qayyum A. Frequency of incidentally diagnosed prostate carcinoma in transurethrally resected prostate specimens. J Postgrad Med Inst 2017;31(4):357-60.

15. Trpkov K1, Thompson J, Kulaga A, Yilmaz A. How much tissue sampling is required when unsuspected minimal prostate carcinoma is identified on transurethral resection? Arch Pathol Lab Med 2008;132(8):1313-6.

16. Varghese J, Kuruvilla MP, Mehta N, Rathore RS, Babu M, Bansal B, et al. Incidentally Detected Adenocarcinoma Prostate in Transurethral Resection of Prostate Specimens: a Hospital Based Study from India. Asian Pac J Cancer Prev 17(4), 225558.

17. Thapa N, Shris S, Pokharel N, Tambay YG, Kher YR, Acharya $S$. Incidence of carcinoma prostate in transurethral resection specimen in a teaching hospital of Nepal. Journal of Lumbini Medical College 2016;4(2):77-9.

18. İhvan AN, Ediz C, Koç N. İnsidental Prostat Kanserine Eşlik Eden Histopatolojik Parametreler. Bulletin of Urooncology 2016;15:48-51.

19. Aslan G, Mammadov E, Kizer O, Tuna B, Yörükoğlu K. Biyopside yüksek dereceli prostatik intraepitelyal neoplazi veya malignite kuşkulu odak varlığında tur-p sonuçları. DEÜ Tip Fakültesi Dergisi 2010;24(3):113-7.

20. Karadağ MA, Çeçen K, Demir A, Bağcıŏlu M, Kocaaslan R, Sofikerim M. Prostat kanserinde fokal tedavi alternatifleri. Kafkas J Med Sci 2015;5(1):18-24.

21. Palisaar JR, Wenske S, Sommerer F, Hinkel A, Noldus N. Open radical retropubic prostatectomy gives favourable surgical and functional outcomes after transurethral resection of the prostate. BJU International 2009; 104:611-5. 